\title{
Relative abundance of pond snails in Turnbull National Wildlife Refuge, Washington, and the spread of an invasive snail
}

\author{
Michele D. Larson ${ }^{1,3},{ }^{*}$, Christina M. Torrieri ${ }^{1}$, and A. Ross Black ${ }^{1,2}$ \\ ${ }^{1}$ Eastern Washington University, Department of Biology, 258 Science Building, Cheney, WA 99004 \\ 2Email: rblack@ewu.edu \\ ${ }^{3}$ Present address: University of Wyoming, Zoology and Physiology, Program in Ecology, Laramie, WY 82072
}

\begin{abstract}
AвSTRACT.-Freshwater gastropods comprise a diverse and highly imperiled taxonomic group that is threatened by anthropogenic factors including the introduction of nonnative species. We surveyed 10 wetland ponds in Turnbull National Wildlife Refuge to assess the possible expansion of the nonnative European ear snail (Radix auricularia) and to determine the genus richness and relative abundance of native gastropods. D-frame dip nets were used to sample gastropods at 4 locations in each pond. Six genera of gastropods were found, including R. auricularia in 6 ponds where it was not previously known. Radix auricularia is now the dominant genus in Middle Pine and Lower Pine Lakes, with relative abundances of $84.13 \%$ and $92.31 \%$, respectively. Due to the high abundance and spread of R. auricularia in Turnbull National Wildlife Refuge, resource managers need to investigate the snail's impacts and implement strategies to reduce possible negative effects of this nonnative snail on native gastropods and other wildlife.
\end{abstract}

RESUMEN.-Los gasterópodos de agua dulce son taxones muy diversos que se encuentran amenazados por factores antropogénicos, estos incluyen la introducción de especies no nativas. Para determinar la posible expansión, así como la riqueza de género y la abundancia relativa de gasterópodos nativos, evaluamos la posible propagación del caracol europeo no nativo (Radix auricularia) en diez estanques, en el Refugio Nacional de Vida Silvestre Turnbull. Para muestrear gasterópodos en cuatro zonas de cada estanque, se usaron redes de inmersión con marco en forma D. Se encontraron seis géneros de gasterópodos, incluyendo $R$. auricularia, que fue encontrado en seis lagunas en las que anteriormente no se conocía que habitara. Radix auricularia es ahora el género dominante en los lagos Middle Pine y Lower Pine, con una abundancia relativa de $84.13 \%$ y de $92.31 \%$, respectivamente. Debido a la alta abundancia y propagación de R. auricularia en el Refugio Nacional de Vida Silvestre Turnbull, los administradores de recursos necesitan investigar su impacto e implementar estrategias, para reducir el posible efecto negativo sobre los gasterópodos nativos y demás animales salvajes.

In North America over $70 \%$ of freshwater gastropods are listed as imperiled or presumed extinct (Lysne et al. 2008, Evans and Ray 2010). The main factors for reduced gastropod diversity are habitat loss, water pollution, and the introduction of invasive species (Lysne et al. 2008, Strong et al. 2008). The effects of invasive species on aquatic ecosystems are often irreversible and lead to reduced biodiversity due to predation on and competition with native species (Strayer 1999, Lysne et al. 2008). Invasive gastropods threaten the diversity of native gastropods by consuming large amounts of primary producer biomass (Riley et al. 2008, Strayer 2010) and altering ecosystem functions (Hall et al. 2003, Arango et al. 2009).
One nonnative gastropod for which we have only limited information about its effects in native ecosystems is the European ear snail (Radix auricularia). This nonnative gastropod is found in 22 of the 50 United States (Brown et al. 2008), including California, Idaho, Montana, Oregon, and Washington (Kipp et al. 2017). Radix auricularia is native to Eastern Europe and temperate Asia where it resides in slow-moving rivers and streams, ponds, lakes, and wetlands. This species has a wide tolerance for temperatures $\left(4{ }^{\circ} \mathrm{C}\right.$ to $\left.32{ }^{\circ} \mathrm{C}\right)$ and specific electrical conductivities (200 to 1200 $\mu \mathrm{S} / \mathrm{cm}$; Spyra 2010, Vinarski and Serbina 2012, von Oheimb et al. 2016). In areas of Eastern Europe, R. auricularia has reached

*Corresponding author: mlarso22@uwyo.edu 


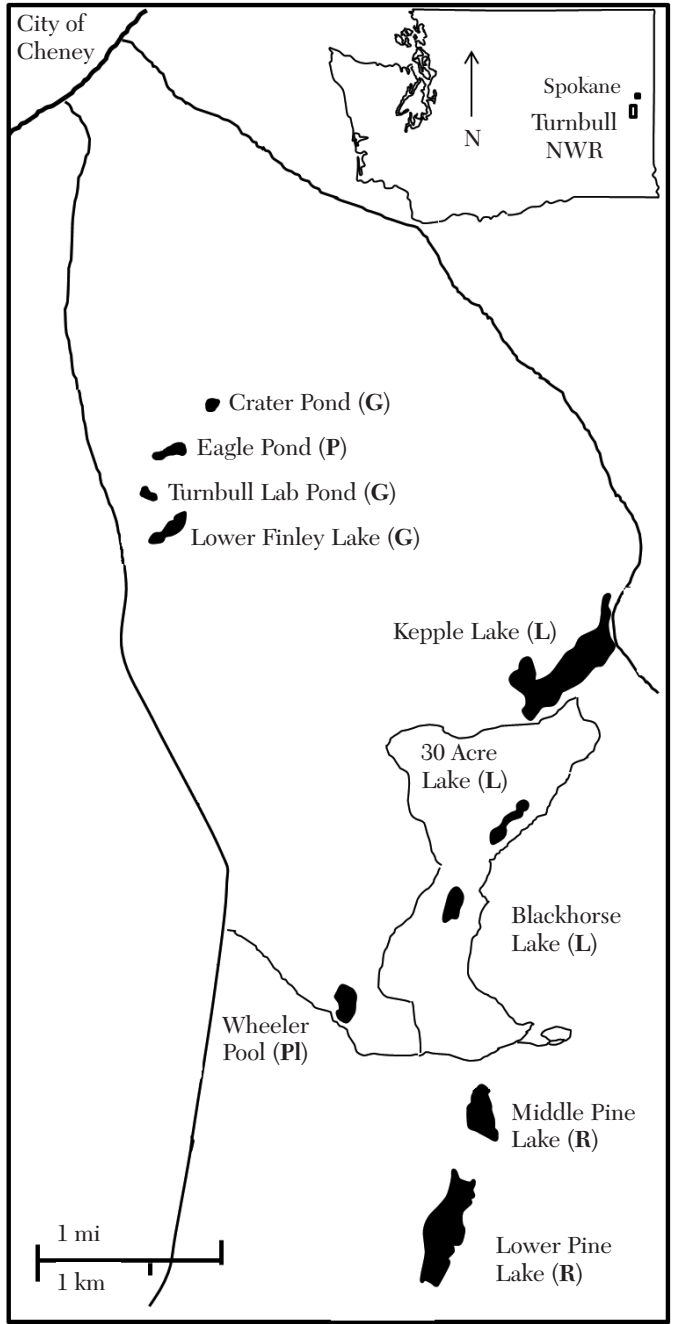

Fig. 1. Location of Turnbull National Wildlife Refuge in Washington State (inset) with the locations of the 10 wetland ponds surveyed in our study. All locations were in the public access area or in the Eastern Washington University Turnbull Laboratory for Ecological Studies area of the refuge. The symbols in parentheses indicate the dominant genus at each pond: Gyraulus sp. (G), Lymnaea sp. (L), Physa sp. (P), Planorbella sp. (Pl), Radix auricularia (R).

high population sizes, accounting for up to $54.4 \%$ of snail abundance and $23 \%$ of snail biomass (Vinarski and Serbina 2012). Additionally, Adam and Lewis (1992) have shown that in permanent lentic environments, $R$. auricularia can compete with native snails.

Because $R$. auricularia was known to reside in Middle Pine Lake in Turnbull National Wildlife Refuge (TNWR; Kipp et al. 2017), we conducted a survey of wetland ponds in the refuge to determine the relative abundance and genus richness of native gastropods while also determining whether the nonnative European ear snail had expanded its range. We predicted that $R$. auricularia had expanded its range in the refuge and that it would be the dominant snail genera in some ponds.

We assessed gastropod relative abundance by dip-net sampling in wetland ponds in TNWR $\left(47.4^{\circ} \mathrm{N}, 117.6^{\circ} \mathrm{W}\right)$, which is located $10 \mathrm{~km}$ south of Cheney, Washington (Fig. 1). We surveyed snails from 10 wetland ponds (areas with $<3 \mathrm{~m}$ of water, high densities of macrophytes, and seasonal changes in surface area and volume) in the public access area or in the Eastern Washington University Turnbull Laboratory for Ecological Studies area of TNWR during May and June of 2012. Sampled ponds were dominated by large emergent macrophytes including cattails, grasses, and sedges. Wetland ponds experienced seasonal drying of the shoreline and reduction in surface area during the summer.

We sampled each pond at 4 sites that were separated by at least $100 \mathrm{~m}$ and located at each cardinal direction, resulting in a total of 4 samples for each pond surveyed. Using a Dframe dip net, we sampled each site in the first meter from the waterline and to a depth of $0.5 \mathrm{~m}$. The D-frame dip net for sweep net sampling in wetlands has been shown to provide evenly distributed relative abundances, yield the most macroinvertebrate taxa, and have the lowest coefficient of variation between samples (Turner and Trexler 1997). Each site had a total of 3 min of sampling effort that was followed by shoreline cleaning of samples (using multiple buckets of filtered pond water to remove vegetation and mud) following methods of Prezant and Chapman (2004); however, a stack of sieves (including $500-\mu \mathrm{m}$, $1.4-\mathrm{mm}$, and $2.8-\mathrm{mm}$ sieves) were used instead of a single $5 \mathrm{~mm}$ sieve in order to retain smaller snails. Specimens were preserved in $70 \%$ ethanol before identification to genus using Brown (2001). We calculated relative abundance of each snail genus in each pond by dividing the total number of snails of one genus by the total number of snails in that pond.

We found 6 different genera of pulmonate snails from 3 families (Lymnaeidae, Physidae, and Planorbidae) with a mean genus richness of 4.4 per pond and a range of 2 to 6 genera in a pond (Table 1). We found 3 genera of 
TABLE 1. Genus richness and relative abundance of snails surveyed from 10 wetland ponds on Turnbull National Wildlife Refuge, Washington. Collection date in 2012 for each pond is shown in parentheses next to the pond name. The bold number represents the relative abundance of the dominant genus for each pond.

\begin{tabular}{|c|c|c|c|c|c|c|c|c|}
\hline \multirow[b]{2}{*}{ Pond (sample date) } & \multirow{2}{*}{$\begin{array}{c}\text { Snails } \\
(n)\end{array}$} & \multirow{2}{*}{$\begin{array}{l}\text { Genus } \\
\text { richness }\end{array}$} & \multicolumn{6}{|c|}{ Snail genus } \\
\hline & & & Gyraulus & Planorbella & Physa & Lymnaea & Fossaria & Radix \\
\hline Turnbull Lab (1 May) & 898 & 5 & $41.1 \%$ & $1.34 \%$ & $31.2 \%$ & $24.4 \%$ & $2.0 \%$ & $0.0 \%$ \\
\hline Eagle (4 May) & 2571 & 6 & $40.0 \%$ & $0.16 \%$ & $47.7 \%$ & $11.9 \%$ & $0.1 \%$ & $0.3 \%$ \\
\hline Crater (7 May) & 621 & 4 & $86.5 \%$ & $0.16 \%$ & $7.6 \%$ & $0.2 \%$ & $0.0 \%$ & $0.0 \%$ \\
\hline Lower Finley (9 May) & 621 & 6 & $65.2 \%$ & $7.89 \%$ & $4.7 \%$ & $13.0 \%$ & $7.1 \%$ & $2.1 \%$ \\
\hline 30 Acre (16 May) & 456 & 4 & $6.6 \%$ & $0.0 \%$ & $45.0 \%$ & $48.1 \%$ & $0.0 \%$ & $0.4 \%$ \\
\hline Kepple (18 May) & 232 & 5 & $7.3 \%$ & $20.3 \%$ & $3.9 \%$ & $56.5 \%$ & $0.0 \%$ & $12.1 \%$ \\
\hline Blackhorse (21 May) & 280 & 5 & $13.2 \%$ & $9.6 \%$ & $3.6 \%$ & $72.9 \%$ & $0.0 \%$ & $0.7 \%$ \\
\hline Wheeler (28 June) & 511 & 4 & $41.3 \%$ & $47.4 \%$ & $0.2 \%$ & $11.2 \%$ & $0.0 \%$ & $0.0 \%$ \\
\hline Middle Pine (14 May) & 397 & 5 & $0.0 \%$ & $6.6 \%$ & $6.8 \%$ & $0.3 \%$ & $2.3 \%$ & $84.1 \%$ \\
\hline Lower Pine (27 Jun) & 13 & 2 & $0.0 \%$ & $0.0 \%$ & $7.7 \%$ & $0.0 \%$ & $0.0 \%$ & $92.3 \%$ \\
\hline
\end{tabular}

TABLE 2. Comparison of 8 gastropod surveys showing the number of gastropod species and genera for aquatic ecosystems found throughout the Northern Hemisphere.

\begin{tabular}{lcccl}
\hline Location & Habitat & $\begin{array}{c}\text { Number } \\
\text { of species }\end{array}$ & $\begin{array}{c}\text { Number } \\
\text { of genera }\end{array}$ & Source \\
\hline Northumberland, UK & 52 ponds & 14 & 12 & Zealand and Jeffries 2009 \\
Idaho, USA & 4 high-elevation lakes & 15 & 9 & Lysne et al. 2011 \\
Arkansas, USA & 1 bayou drainage & 13 & 12 & Minton et al. 2008 \\
Lake Michigan, USA & 9 insular lakes & 18 & 13 & Harris et al. 2011 \\
Michigan, USA & 37 ponds & 24 & 17 & Hoverman et al. 2011 \\
Idaho, USA & 1 river/reservoir & 11 & 10 & Lysne and Clark 2009 \\
Kaliningrad, Russia & 3 coastal lakes/1 river & 29 & 11 & Filippenko 2011 \\
Pennsylvania, USA & 398 streams and springs & 37 & 22 & Evans and Ray 2010 \\
\hline
\end{tabular}

Lymnaeidae (Lymnaea, Radix, and Fossaria), 1 genus of Physidae (Physa), and 2 genera of Planorbidae (Gyraulus and Planorbella) at different relative abundances in the 10 ponds surveyed (Table 1), with the dominant genus in each pond constituting over $40 \%$ of the relative abundance for that pond. The invasive snail $R$. auricularia was found in 7 ponds, with relative abundances between $0.3 \%$ in Eagle Pond and 92.3\% in Lower Pine Lake (Table 1). We found that the dominant genus varied among ponds, with $R$. auricularia being the dominant genus at Middle Pine and Lower Pine Lakes (Table 1).

Our survey of gastropods at TNWR showed results that were similar to 2 studies of gastropods in Idaho. In a survey of 4 high-elevation lakes, Lysne et al. (2011) found 5 families and 9 genera of gastropods, which included all of the families and 5 of the 6 genera found at TNWR. Gastropods surveyed in a river and reservoir in southern Idaho showed the same pattern, with all 3 families and 5 genera in common with those found at TNWR (Lysne and Clark 2009). Radix auricularia was found in both of the surveys conducted in Idaho (Lysne and Clark 2009, Lysne et al. 2011).

Gastropod genus richness in TNWR appears to be lower than in other ecosystems. In 8 gastropod surveys, genus richness ranged from 9 to 22 (Table 2 ), whereas only 6 genera were found in TNWR. Possible explanations for the low genus richness at TNWR include pond surface area (Hrabik et al. 2005, Harris et al. 2011, Hoverman et al. 2011), pH (Dillon 2000, Harris et al. 2011, Hoverman et al. 2011), conductivity (Dillon 2000, Hrabik et al. 2005, Harris et al. 2011), predator presence and abundance (Brönmark 1992, Brown et al. 1998, Turner and Chislock 2007, Michot et al. 2008, Covich 2010), and anthropogenic effects (Rohr and Crumrine 2005, Evans and Ray 2010) such as interactions with invasive species (Strayer 1999, Lysne et al. 2008, Riley et al. 2008, Strayer 2010) including $R$. auricularia (Adam and Lewis 1992).

The expansion of $R$. auricularia in the wetlands of TNWR is troubling. Radix auricularia was previously known from a single historic population (first recorded in 1968) at Middle 
Pine Lake (Kipp et al. 2017) but has expanded its range to include 6 additional ponds and has become the dominant genus in Middle Pine and Lower Pine Lakes (Table 1). Although $R$. auricularia has been in TNWR for approximately 50 years, we do not have a definitive date of first introduction or any subsequent data on expansion during this period prior to our survey. We therefore cannot attest to the rate of spread of this invasive snail over time. However, the spread of R. auricularia from Middle Pine Lake to Lower Pine Lake is expected because these 2 lakes are connected by an intermittent stream. The higher abundance of this nonnative snail in Kepple Lake may be attributed to the relatively large size of the lake (it was the largest lake in our survey), which may have increased the likelihood that ducks and other waterfowl would transport snail eggs or juveniles to this pond. Because TNWR is a refuge managed for migrating waterfowl, this method of dispersal may account for $R$. auricularia's dispersal to ponds not connected during high flow events (Boag 1986). Alternatively, the spread of $R$. auricularia may be due to human activities, including the unintentional transport of eggs and small snails on equipment and waders during pond maintenance, scientific or management surveys, or waterfowl hunts. Resource managers need to increase awareness of invasive species in their areas of authority by educating the public in how to reduce transmission of $R$. auricularia and other invasive species among locations.

The expansion of $R$. auricularia at TNWR may result in lower abundance and diversity of native gastropods. Most freshwater snails feed on periphyton and detritus, and studies have shown that snail survival rates decline during times of food scarcity (Brown 1982, Osenburg 1989). In permanent lentic environments, $R$. auricularia has been shown to reduce and extirpate native snail populations (Adam and Lewis 1992). If $R$. auricularia and native snails in TNWR are competing for the same food source, $R$. auricularia could outcompete native snails, lowering native snail abundance. Additionally, Deng (1997) found that $R$. auricularia preyed on juvenile snails. If $R$. auricularia commonly uses juvenile snails as a food source, then native snail populations may be negatively influenced. Furthermore, if $R$. auricularia has better defenses than native snails or is inedible to native predators in invaded ecosystems, then native snails may experience increased predation rates because the less desirable $R$. auricularia would be avoided by predators. Differential predation of snail species has been shown for dragonfly nymphs (Younes et al. 2016), fly larvae (Fu and Meyer-Rochow 2012), and water bug adults (Younes et al. 2017).

Another way that native snails could be affected by $R$. auricularia is through trematode parasite interactions. In its native range, $R$. auricularia is commonly infected with a dozen different trematode parasites (Adam and Lewis 1993, Soldanova et al. 2010) that ultimately inhabit piscivorous birds, waterfowl, and mammals, including livestock. In introduced areas, $R$. auricularia has been found with trematode infections (Larson 2018). Thus, $R$. auricularia could bring nonnative parasites that may infect native snails or it could act as a reservoir host, increasing the parasite population and potentially increasing infections in native snails. The invasive species could, however, act as a decoy host resulting in a reduced parasite population and diluting the number of infections in native snails (Torchin and Mitchell 2004, Telfer and Bown 2012).

More research on the presence of $R$. auricularia in eastern Washington wetlands would give a better understanding of the scope of this nonnative species in these ecosystems. The extent to which $R$. auricularia competes with native snails could be determined through competition experiments, grazing trials, and stable isotope analysis. It would also be beneficial for managers to determine whether $R$. auricularia in eastern Washington are harboring trematode parasites that can infect waterfowl, wildlife, or livestock to determine whether there are risks of transmission to these species.

Our survey of gastropods in TNWR showed lower genus richness than observed in similar gastropod surveys. Because gastropods are an important food and calcium resource for waterfowl (Petrie 1996, Scheuhammer et al. 1997, Ross et al. 2005, Michot et al. 2008), resource managers at TNWR and other public lands need to assess their gastropod populations to determine whether low richness levels are associated with lower waterfowl populations. Additionally, the effects of invasive species on 
wetland ecosystems need to be quantified to determine whether these organisms are having negative impacts on native populations.

\section{ACKNOWLEDGMENTS}

We would like to thank M. Rule for permits and access to TNWR. We also thank J. Ponce for assistance in the field and A. Scholz for access to fish survey data. We are grateful for the comments of K. Anicito, R. Brown, A. Gebauer, C. McNeely, C. Schucker, S. Schwab, and 4 anonymous reviewers.

\section{Literature Cited}

Adam, M.E., AND J.W. LeWIs. 1992. The lack of co-existence between Lymnaea peregra and Lymnaea auricularia (Gastropoda: Pulmonata). Journal of Molluscan Studies 58:227-231.

ADAM, M.E., AND J.W. LEWIS. 1993. The role of Lymnaea auricularia (Linnaeus) and Lymnaea perecra (Muller) (Gastropoda: Pulmonata) in the transmission of larval digeneans in the lower Thames Valley. Journal of Molluscan Studies 59:1-6.

Arango, C.P., L.A. Riley, J.L. Tank, and R.O. Hall Jr. 2009. Herbivory by an invasive snail increases nitrogen fixation in a nitrogen-limited stream. Canadian Journal of Fisheries and Aquatic Science 66: 1309-1317.

BOAG, D.A. 1986. Dispersal in pond snails: potential role of waterfowl. Canadian Journal of Zoology 64: 904-909.

BRÖNMARK, C. 1992. Leech predation on juvenile freshwater snails: effects of size, species, and substrate. Oecologia 91:526-529.

Brown, K.M. 1982. Resource overlap and competition in pond snails: an experimental analysis. Ecology 63: $412-422$.

Brown, K.M. 2001. Mollusca: Gastropoda. Pages 297-325 in J.H. Thorp and A.P. Covich, editors, Ecology and classification of North American freshwater invertebrates. Academic Press, San Diego, CA.

Brown, K.M., J.E. Alexander, and J.H. Thorp. 1998 Differences in the ecology and distribution of lotic pulmonate and prosobranch gastropods. American Malacological Bulletin 14:91-101.

Brown, K.M., B. Lang, and K.E. Perez. 2008. The conservation ecology of North American pleurocerid and hydrobiid gastropods. Journal of the North American Benthological Society 27:484-495.

Covich, A.P. 2010. Winning the biodiversity arms race among freshwater gastropods: competition and coexistence through shell variability and predator avoidance. Hydrobiologia 653:191-215.

DENG, L. 1997. Study on the effect of predation on Radix auricularia on the junior snail of Parafossarulus striatulus of first intermediate host of Clonorchis sinensis. Chinese Journal of Zoonoses 13:47-48.

Dillon, R.T., JR. 2000. The ecology of freshwater molluscs. Cambridge University Press, New York, NY.

Evans, R.R., And S.J. RaY. 2010. Distribution and environmental influences on freshwater gastropods from lotic systems and springs in Pennsylvania, USA, with conservation recommendations. American Malacological Bulletin 28:135-150.

FilippenKo, D.P. 2011. Distribution and environmental influences on freshwater gastropods from lotic systems and springs in Pennsylvania, USA, with conservation recommendations. American Malacological Bulletin 28:135-150.

FU, X., AND V.B. MEYer-Rochow. 2012. An investigation into the morphological and behavioral adaptations of the aquatic larvae of Aquatica leii (Coleoptera: Lampyridae) to prey upon freshwater snails that serve as intermediate hosts for the liver fluke. Biological Control 62:127-134.

Hall, R.O., Jr., J.L. Tank, and M.F. Dybdahl. 2003. Exotic snails dominate nitrogen and carbon cycling in a highly productive stream. Frontiers in Ecology and the Environment 1:407-411.

Harris, A.T., D.A. Woolnough, and D.T. Zanatta. 2011. Insular lake island biogeography: using lake metrics to predict diversity in littoral zone mollusk communities. Journal of the North American Benthological Society 30:997-1008.

Hoverman, J.T., C.J. Davis, E.E. Werner, D.K. Skelly, R.A. Relyea, and K.L. Yurewicz. 2011. Environmental gradients and the structure of freshwater snail communities. Ecography 34:1049-1058.

Hrabik, T.R., B.K. Greenfield, D.B. Lewis, A.I. Pollard, K.A. Wilson, and T.K. Kratz. 2005. Landscape-scale variation in taxonomic diversity in four groups of aquatic organisms: the influence of physical, chemical, and biological properties. Ecosystems 8:301-317.

Kipp, R.M., A.J. Benson, J. Larson, and A. Fusaro. 2017. Radix auricularia. USGS Nonindigenous Aquatic Species Database, Gainesville, FL; [accessed 4 May 2017]. http://nas.er.usgs.gov/queries/factsheet.aspx ?SpeciesID $=1012$

LARSON, M.D. 2018. Range expansion and parasitism in the nonnative snail Radix auricularia. Western North American Naturalist 78:112-116.

Lysne, S.J., AND W.H. CLARK. 2009. Mollusc survey of the lower Bruneau River, Owyhee County, Idaho, U.S.A. American Malacological Bulletin 27:167-172.

Lysne, S.J., G. Garcia, AND B.R. Krouse. 2011. Molluscan community composition and richness in four high-elevation Idaho streams includes an exotic taxon. American Malacological Bulletin 29:127-133.

Lysne, S.J., K.E. Perez, K.M. Brown, R.L. Minton, and J.D. SIDES. 2008. A review of freshwater gastropod conservation: challenges and opportunities. Journal of the North American Benthological Society 27: $463-470$.

Michot, T.C., M.C. Woodin, and A.J. Nault. 2008. Food habits of Redheads (Aythya americana) wintering in seagrass beds of coastal Louisiana and Texas, USA. Acta Zoologica Academiae Scientiarum Hungaricae $54: 239-250$.

Minton, R.L., J.D. White, D.M. Hayes, M.S. CheNOWETH, AND A.M. HiLl. 2008. Diversity and distribution of freshwater gastropods in the Bayou Bartholomew drainage, Arkansas, U.S.A. American Malacological Bulletin 26:171-177.

Osenberg, C.W. 1989. Resource limitation, competition and the influence of life history in a freshwater snail community. Oecologia 79:512-519.

Petrie, S.A. 1996. Red-billed Teal foods in semiarid South Africa: a north-temperate contrast. Journal of Wildlife Management 60:874-881. 
Prezant, R.S., and E.J. Chapman. 2004. Freshwater molluscs of the United States Military Academy drainages (West Point, NY) and comparative regional biodiversity of gastropods. Northeastern Naturalist 11: 273-294.

Riley, L.A., M.F. Dybdahl, and R.O. Hall Jr. 2008. Invasive species impact: asymmetric interactions between invasive and endemic freshwater snails. Journal of the North American Benthological Society $27: 509-520$.

Rohr, J.R., AND P.W. Crumrine. 2005. Effects of an herbicide and an insecticide on pond community structure and processes. Ecological Applications 15: 1135-1147.

Ross, R.K., S.A. Petrie, S.S. Badzinski, and A. Mullie. 2005. Autumn diet of Greater Scaup, Lesser Scaup, and Long-tailed Ducks on eastern Lake Ontario prior to zebra mussel invasion. Wildlife Society Bulletin 33:81-91.

Scheuhammer, A.M., D.K. McNicol, M.L. Mallory, AND J.J. KereKes. 1997. Relationships between lake chemistry and calcium and trace metal concentrations of aquatic invertebrates eaten by breeding insectivorous waterfowl. Environmental Pollution 96:235-247.

Soldanova, M., C. Selbach, B. Sures, A. Kostudinova, AND A. PEREZ-DEL-Olmo. 2010. Larval trematode communities in Radix auricularia and Lymnaea stagnalis in a reservoir system of the Ruhr River. Parasites and Vectors 3:56. https://doi.org/10.1186/ 1756-3305-3-56.

SpYra, A. 2010. Environmental factors influencing the occurrence of freshwater snails in woodland water bodies. Biologia 65:697-703.

StraYer, D.L. 1999. Effects of alien species on freshwater mollusks in North America. Journal of the North American Benthological Society 18:74-98.

Strayer, D.L. 2010. Alien species in fresh waters: ecological effects, interactions with other stressors, and prospects for the future. Freshwater Biology 55: $152-174$.

Strong, E.E., O. Gargominy, W.F. Ponder, and P. BOUCHET. 2008. Global diversity of gastropods (Gastropoda, Mollusca) in freshwater. Hydrobiologia 595: 149-166.
Telfer, S., AND K. Bown. 2012. The effects of invasion on parasite dynamics and communities. Functional Ecology 26:1288-1299.

Torchin, M.E., And C.E. Mitchell. 2004. Parasites, pathogens, and invasions by plants and animals. Frontiers in Ecology and the Environment 2:183-190.

Turner, A.M., And M.F. Chislock. 2007. Dragonfly predators influence biomass and density of pond snails. Oecologia 153:407-415.

Turner, A.M., And J.C. Trexler. 1997. Sampling aquatic invertebrates from marshes: evaluating the options. Journal of the North American Benthological Society 16:694-709.

Vinarski, M.V., and E.A. Serbina. 2012. Distribution and quantitative characteristics of common species of pond snails of the subgenera Peregriana and Radix (Mollusca: Gastropoda: Lymnaeidae) in waterbodies of the South of Western Siberia. Inland Water Biology 5:37-44.

vON OHEIMB, P.V., L. LANDLER, and K.C.M. von OHEImb. 2016. Cold snails in hot springs: observations from Patagonia and the Tibetan Plateau. Malacologia 59: 313-320.

Younes, A., H. El-Sherief, F. GaWish, and M. Mahmoud. 2016. Experimental evaluation of Odonata nymph in the biocontrol of schistosomiasis intermediate hosts. Asian Pacific Journal of Tropical Biomedicine 6: 995-1000

Younes, A., H. El-Sherief, F. Gawish, and M. Mahmoud. 2017. Biological control of snail hosts transmitting schistosomiasis by the water bug, Sphaerodema urinator. Parasitology Research 116:1257-1264.

ZEaLAND, A.M., AND M.J. JefFries. 2009. The distribution of pond snail communities across a landscape: separating out the influence of spatial position from local habitat quality for ponds in south-east Northumberland, UK. Hydrobiologia 632:177-187.

Received 14 September 2017

Revised 9 March 2018

Accepted 6 April 2018

Published online 7 July 2018 